\title{
UNIVERSITYOF
}

FORWARD

THINKING

WESTMINSTER用

WestminsterResearch

http://www.westminster.ac.uk/westminsterresearch

Translating Protestant Christianity into China: Questions of

Indigenization and Sinification in a Globalized World

Wielander, G.

Wielander, G. (2016) Translating Protestant Christianity into China: Questions of Indigenization and Sinification in a Globalized World in: Blumczynski, P. and Gillespie, J. (eds.) Translating Values: Evaluative Concepts in Translation London Palgrave Macmillan. pp. 213-235, 2016, Palgrave Macmillan, reproduced with permission of Palgrave Macmillan.

This extract is taken from the author's original manuscript and has not been edited. The definitive, published, version of record is available here:

https://dx.doi.org/10.1057\%2F978-1-137-54971-6 11

The WestminsterResearch online digital archive at the University of Westminster aims to make the research output of the University available to a wider audience. Copyright and Moral Rights remain with the authors and/or copyright owners.

Whilst further distribution of specific materials from within this archive is forbidden, you may freely distribute the URL of WestminsterResearch: ((http://westminsterresearch.wmin.ac.uk/)).

In case of abuse or copyright appearing without permission e-mail repository@westminster.ac.uk 
Gerda Wielander

\section{Translating Protestant Christianity into China - Questions of Indigenization and Sinification in a Globalised World}

\section{Introduction}

Growing up in Catholic Austria, one of my earliest memories is attending Mass in a tiny rural church close to the Czech border. The elderly priest, his back turned to the congregation, performed the Mass in Latin, while the small congregation spent the hour in a semimeditative state looking out for the familiar cues that ordered them to kneel, sing, or come forward for Holy Communion. What was said - the message of the gospel - was entirely secondary to the ritual that was being performed. This religious experience stands in stark contrast to the type of Mass I attended in China in recent years, where the word of the Bible takes centre stage, be it at the enthusiastic big meetings in Haidian Church or the contemplative 'sharing and caring' atmosphere in small private churches in Sichuan.

As far as Christianity is concerned, the Chinese Communist party considers Catholicism and Protestantism to be two different faiths. They are two of the five officially recognised religions in Communist China; the other three are Buddhism, Taoism, and Islam. Of the five, only Taoism is considered to be an indigenous religion. Christianity, and in particular Protestantism, is closely associated with Western imperialism, primarily because Protestant missionary efforts benefitted immensely from the various concessions granted in the so-called 'unequal treaties' China was forced to sign with a number of European nations in the nineteenth and early twentieth centuries. The role of the Protestant missionary has been controversial, and ambivalent. While the foreign missionary was the incarnation of evil for 
the rebels of the Boxer Rebellion in 1900, Protestant missionary endeavours undeniably contributed both directly and indirectly to China's modernization process in the fields of education, healthcare, women's liberation, and political reform. Both Sun Yat-sen, the founder of the Republic of China in 1911, and Chiang Kai-shek were Christians (Bieler and Hamrin 2009).

Crucially, Christian missionaries were also translators and proponents of intercultural dialogue. The translational encounter was always the product of interaction between Chinese and Western belief and influenced on each side by the debates of the time. Both missionaries and Chinese scholars in the nineteenth and twentieth century brought their own cultural heritages, their faith and their desire to modernize China to the reading and interpretation of the scriptures (Starr 2008: 3-4). Of all these factors, the denomination an individual belonged to, the social context of the times, and the political viewpoint he/she held, have all impacted and continue to impact the way the Christian faith is translated into the Chinese language and cultural context today.

Long before the 'discovery' of the cultural turn in translation studies, the transaction between the Christian missionaries and their Chinese collaborators was much more than a 'transaction between two languages, or a somewhat mechanical sounding act of linguistics "substitution" [...] but rather a more complex negotiation between two cultures' (Trivedi 2005). The translation of the Bible into Chinese, and the subsequent and continuous interpretation of this text, provides one of the best examples of where the unit of translation goes well beyond word and text, but consists of 'the whole language and culture in which that text was constituted', to use again Trivedi's (2005) words.

This chapter provides a brief historical overview of the translational encounter and the various translational difficulties encountered during the nineteenth century, which resulted in the publication of the Chinese Union Version in 1919. It will spend some time exploring the 
key attraction of Christianity at this particular moment in history as well as the emerging points of contention and disagreement between different Chinese Christian leaders. It then focuses on Bishop K.H. Ting's (Ding Guangxun, 1915-2012) attempts to create a 'theology rooted in the Chinese soil', an example of how core Christian values have been negotiated in this process of translation into a very specific Chinese cultural context. Ting's theology illustrates the tension between localization and the retention of the universality of the Christian faith. Most recently this tension has given rise to two different paradigms: the idea of hanyu shenxue, a Chinese language theology, and the expectation of zhongguohua, or 'China-fication', of Protestant Christianity.

\section{The Significance of the Union Version}

The first full translation of the Protestant Bible printed in Chinese appeared in 1820, only a few years after the arrival of the first Protestant missionary in China (the first Catholic Bible, on the other hand, did not appear until 1961, 700 years after a Catholic missionary first set foot in China). Its name was translated into Chinese as shengjing, literally 'Holy Classic', which by the 1840s was the most commonly used term for the Bible. Jing, classic, implies authority and canonical status, in line with the wujing (five classics) of Chinese traditional learning; it also implied how it should be read, i.e. recited by heart and ingrained in the educated mind (Starr 2008: 3). The translation relied heavily on collaboration with mostly unnamed Chinese translators. They were also highly dependent on the efforts of other translators, notably earlier Catholic translational efforts.

In the process of translating the Bible into Chinese, both Western missionary translators and their Chinese collaborators broke new ground, not only by questioning established paradigms on the purpose of a translated text, but also through the choices they made in relation to the style of Chinese into which they translated. In the $19^{\text {th }}$ century they 
could choose between Classical Chinese (high classical or easy classical), the language of the literati and court elite, which had no resemblance to the spoken language of the people, or 'guanhua', literally the 'language of government officials' or 'Mandarin', which served as a lingua franca for the administration of an empire, in which countless different dialects and languages existed. The Bible was also translated into dialects and minority languages.

The choices they took were influenced by new principles of translation, which became central to the translation project in the middle of the nineteenth century. At a time when there was only one authorized English version of the Bible and when there existed a belief in the literally unchangeable word of God in the Bible, missionary translation teams decided that the translation should no longer be determined by strict fidelity to the source text, but also by the language into which it was to be translated and the cultural situation of the reader (Zetzsche 1999: 74). In this context, a gap opened between British and American missionaries and translators. While the British trusted in the Chinese culture's ability to receive the Christian message with its own terminology, the American position was that Chinese culture could only receive the Christian message with a new terminology. In other words, the British team of translators tried to build Christianity on a Chinese foundation, whereas the American team believed in installing something entirely different and new. This led to an ever-deepening division in the missionary community, which was further fragmented along denominational lines, including the China Inland Mission, Presbyterians, Seventh Day Adventists, and Baptists, to give but a few examples.

Paradoxically, these divisions led to the most successful Bible translation in the form of the Union Version, published in 1919. Following the deepening conflict mentioned above, the 1890 General Mission Conference focused on the demand for a common effort toward a Chinese translation of the Bible. As a result massive compromises were reached in relation to the most controversial issues, including the choice of styles in Chinese and an agreement on 
the Greek basic text (which served as the source text for the English Revised Version of the Bible). Perhaps the most important decision in terms of translation principles was the employment of a colloquial style of Mandarin - considered not grave enough for the Bible in earlier translation projects - which included the abolition of set literary phrases and a greater fidelity to the Greek text (for a detailed analysis of the process, see Zetzsche 1999).

In the context of the early twentieth century Chinese mission, the need for a Bible, which could be understood by the common people, was urgently felt. Protestant missionaries of the nineteenth century, who had gained permission to build churches on Chinese soil, often penetrated deep into the Chinese heartland, proselytizing the common people. Their efforts also coincided with China's modernization efforts, which saw major works of Western literature as well as science and technology translated into Chinese, often via Japanese. The importance of a new form of written language, which reflected the syntax and lexis of the spoken Chinese language of the time, took centre stage. The many translations also meant that Chinese lexis was greatly expanded, introducing new words and concepts into the language.

The translation of the Bible into China therefore took place during a high point of translational activity, which must be added to the three distinct 'moments' Trivedi (2005) identifies over the span of the $20^{\text {th }}$ century. Even more than the translations of Latin American and East European literatures into English, these translations of European literature and canonical texts of all kinds helped to transform Chinese expectations of what literature looks like or should look like, but also what the future might look like. These translations not only opened up new worlds of concepts and ideas, but also created a new language.

A reform of the written language to eliminate the gap between the spoken and the written word - which by 1900 was as wide as the gap between the Austrian priest's Latin and the German vernacular of his congregation - was a key element of the May Fourth 
Movement, which takes its name from a protest movement on May Fourth 1919, but which is generally understood to span a number of years around this date. It was an iconoclastic movement calling for a rational, scientific approach to China's crisis and for political reform. The Chinese Union Bible was one of the first works written in the vernacular, or baihua, and thus enjoyed popularity far beyond the Christian Church. Even though not considered final at the time, the Union Version was left unchanged and ended up gaining the status of a 'classic'. It is now the one authorized Bible of the Chinese-speaking world. The Union Version heheben in Chinese, which evokes a spectrum of meanings around harmony, togetherness, collaboration, and unity - is of key symbolic significance for the official Chinese church that sees itself as representing the non-denominational character of Chinese Protestantism.

Due to the significance of the historical moment in which the Union Version was published, the Bible's readership and influence went far beyond the Christian community. As Chen Jianming (2008) points out, the Chinese Bible was read in many different ways and not necessarily as a religious text. Many, who were initially attracted by it, found some of the core Christian tenets 'nonsense', such as the divine nature of Jesus, or the concept of the virgin birth, which continues to be a challenge for the pragmatic Chinese mind. Others read it as a guide to revolution, or as a moral norm to help with the spiritual renewal of the Chinese national character. Perhaps most interestingly, the Bible was also read as a literary work both during the May Fourth Period and again during the 1980s. Many writers of the May Fourth period were familiar with the Union version of the Bible, which served as a source of inspiration for those, whose main concern was to cast a new national language and literature. Some argued that a new literature for a new China also required new spiritual foundations; others considered the Bible as the earliest example of Europeanized literary vernacular Chinese and hence an excellent reference for the creation of a national language. The 
popularity of the Bible also greatly expanded the lexicon of modern Chinese in terms of vocabulary, literary quotations and phrases (Chen 2008: 24-6).

Some scholars go even further. Yuan Jin (2006) proposes a strong link between missionary publications and the development of the Chinese language itself. The fact that Chinese Christian scriptures - as well as many translations of Western books into Chinese had appeared in guanhua (Mandarin) as early as the 1850s, and therefore introduced the vernacular in both literary and religious texts, must have at least contributed to the reception of spoken Chinese as a norm for literature (Strandenaes 2008: 71; also Yuan 2006). Add to this the importance of missionary projects in the development of a modern Chinese press and one begins to understand the complex ways in which Christian missionary activity including the translation of the Bible - contributed to China's modernization.

\section{The Moral Character of Jesus Will Save the Nation}

The Chinese Union Version appeared at a time when Chinese intellectuals were preoccupied with the 'salvation of the Chinese nation'; for many, the Bible, and in particular the character of Jesus Christ, provided a possible answer to the plight of China with all its failures. For non-Christians, the Bible provided inspiration and an insight into the spiritual foundation of the West's 'success'. Christian believers and theologians, however, were confronted with a major quandary, which in many ways continues to this day: how to subscribe to the demands of nationalism and national salvation (of particular importance in the 1920s and 1930s) while remaining true to their faith? At the same time, all Chinese intellectuals, including Christians and theologians, were exposed to new and competing ideologies and '-isms' introduced to China, including socialism, which quickly became one of the most influential theories of modernization. Socialism's appeal to modernisers lay in the fact that it was a Western, but as yet unrealised, vision of a fairer society; it thus provided an alternative pathway to the 
capitalist modernization model of the West. It pointed the way for many Chinese intellectuals, including Christians, in whose (missionary) publications the ideas of socialism were first discussed (Wielander 2016).

One important organization which provided a bridge between socialist and Christian values was the YMCA. It was also the one organization which most actively promoted the 'social gospel', that is, the belief in the importance of addressing social problems as part of missionary work. The Chinese YMCA was founded in 1895 as a direct result of the growth of American missions in Asia during the nineteenth century. The social gospel was conceived in the United States as a solution to the problems arising from the transformation of the agricultural economy, including rampant corruption at all levels of government, unemployment, poverty and working class discontent. Proponents of the social gospel wanted to build a new society based on religious liberalism, humanitarianism and 'social science', marking an adaptation of Christianity to a more modern, scientific world (Keller 1996: 33-5). An important goal of the YMCA's programme was to imbue its members with an 'ethic of community' that would result in voluntary social service and a sense of national identity. It was also the largest institution in China practising 'social reconstruction theology'.

Social reconstruction theology held that Chinese modernization depended upon the reformation of society to include progressive Chinese values by rectifying the character of individuals and that a social vanguard with a Christian value system could actualize the "spirit of Jesus'. Some Chinese adopted this idea as an alternative to revolutionary Marxism. Two of the main leading figures in the establishment of the official Protestant organization after the Communist victory in 1949, T.C. Chao (Zhao Zichen) and Y.T Wu (Wu Yaozong), were proponents of the social gospel and the importance of a social foundation to evangelism. Generally speaking, the figure of Jesus Christ played a central role in the adaptation of 
Christian faith to the Chinese political context in the two decades following the publication of the Union Version.

For some intellectuals, Jesus was the prototypical Christian socialist; his character was one of the most important topics in the early $20^{\text {th }}$ century Church in China. In this context the historical Jesus was at least as important - and seen as somewhat separate - from the Christ of faith. Chinese culture, built on rational, pragmatic and this-worldly 'Confucianism', meant that miracles like the virgin birth, Christ's bodily resurrection, and the ascension were met with great scepticism. The life of Jesus, on the other hand, exemplified virtues like purity, self-denial, service, and love, which chimed with Confucian ethics, and seemed to integrate the religious experience into ethical behaviour. Jesus' salvific work was of less importance to Christian believers. It fell to theologians like T.C. Chao and later K.H. Ting to put equal emphasis on Jesus as moral example and as the means through which to discover communion with God (Wan 1999: 358-9).

In a society built on the Confucian belief in self-perfection and the moral imperative to get involved in the improvement of society, emulating the personal character of Jesus was the starting point for a socialist revolution in the eyes of $\mathrm{Wu}$ Leichuan, for example. This was a view by no means shared by all. The debates of the time reveal a deep chasm over soteriology, namely over the question what salvation meant to the Chinese Christian. As Wan Sze-Kar puts it in his study of Wu Leichuan and T.C. Chao, the appropriation of the narrative of Jesus was caught in the throes of a national crisis; soteriology meant national salvation. But the debate also revealed a more general debate: how could one reconcile the Confucian obligation of transforming society through self-cultivation with a Protestant soteriology that was based on appropriating Christ's death through grace (Wan 1999: 351)?

T.C. Chao argued that the greatest problem for China was the Chinese people - a view shared by many reform intellectuals. Not dissimilar to other intellectuals like Liang 
Qichao and $\mathrm{Lu}$ Xun, Chao argued that the Chinese people needed to change from the inside out if the nation was to achieve political unity and social stability. He believed that the danger to China, and its weakness lay in the rejection of moral character or renge, a concern that many intellectuals in contemporary China also continue to share. To Chao, universal love and moral excellence were the two central principles of Christianity, love being the starting point. He saw the love of God as the only tenable meaning of life. To him, Christianity and Chinese culture were complementary; encouraging the spiritual transformation in the individual would have a direct impact on social reconstruction (Lin 2010: 128-35).

\section{Towards a Chinese Christianity}

The debates in the first half of the twentieth century revolved around issues that remain divisive and unresolved in Chinese theology today. They include different understandings of the mythical and the ethical; the immanent and the transcendent; the intellectual and the spiritual; the historical, fleshly Christ and the Christ of the spirit, which continue to be represented through very different religious practices - for example in rural and urban churches - and through different and contending theological positions. Following the actual translation of the Bible in the form of the Union Version, and despite its canonical status from the start, Christianity was interpreted and adapted into a very particular Chinese context of competing ideologies.

To understand the context of the early twentieth century as Confucian is too simplistic. It was a Confucianism - itself the result of many changes over the centuries - which was in the process of being questioned, reformed, and even rejected outright. In this landscape Christianity was competing with other, 'rational' and atheist voices from the West, like anarchism, socialism, and the newest psychological theories, which exerted an influence in China, and which also shaped the way in which Christianity was 'translated' to fit the new 
environment. It was also in this context that Chinese Christianity was trying to find its own identity, prompted in some ways in the 1920s, by an anti-Christian campaign made up of the dual forces of anti-foreignism and scientism, two of the main tenets of the May Fourth Movement.

In response, Chinese Christians developed an indigenous strategy which relied on the historical Jesus to construct an indigenized theology. The assumption was that Jesus represented the pristine religiosity of Christianity before it was institutionalised and encrusted with Western cultural by-products. This strategy had two benefits, as Wan Sze-Kar points out: it loosened the Chinese church from the grips of tradition, both western theological and ecclesiastical, but also tradition more generally, against which May Fourth railed. It also gave Chinese apologists the freedom to reconceive their Christian project within the context of modern China. This context had to do with national salvation and was dominated by concerns about warlordism, corruption, the collapse of culture, foreign domination and militarism (Wan 1999: 375).

Discussions over the role of the foreign mission in China and movements towards more independence long predated the May Fourth Movement however. English missionaries of the nineteenth century saw their main aim in helping to create an independent Chinese church, a church in which foreign missionaries were no longer important. The establishment of 'The Church of Christ in China' in 1910 signalled this desire to create a new church organization which would be a non-denominational, single Chinese church. Instrumental in the debates over Chinese or foreign leadership of the churches was a group which Daniel Bays (2012: 100-02) calls the 'Sino-Foreign Protestant Establishment'; a group of men who constituted an elite policy-making and decision-making 'establishment' among the great variety of missionaries and missionary organizations in China at the time. 
These well-educated and well-connected intellectuals did not represent the entire scene of foreign missionaries in China at the time. There was a great influx of missionaries of a variety of different creeds and often not part of any wider missionary organization, but driven by their own personal vision and zeal. The 1920s also saw the first beginnings of indigenous Christian groups which grew out of orthodox Christian belief and Chinese popular religion. Daniel Bays reckons that by 1929 as many as a quarter of all Chinese Christians fell into these independent groups (Bays 2012: 115). Finally, the 1920s also saw the creation of the National Christian Council (1922) and the Church of Christ in China (1927), further attempts at establishing a Chinese organization across denominations.

Over the next two decades China was wrapped up in war, and it was only after the end of the Second World War that these efforts at a unified Chinese church were taken up again, this time in a very different political landscape. The 'Chinese Christian Movement' was set up by the National Christian Council, and constituting a link between university centres and the YMCAs and YWCAs. Members were students who were liberal and sympathetic to the Communists and who loosely identified themselves as Christians; one of the movement's main proponents was $\mathrm{Wu}$ Yaozong. Following the establishment of the People's Republic of China in 1949, this group became the launching pad for the so-called 'Three Self Patriotic Movement' (TSPM), which was created in the summer of 1950. At its core was a 'Christian Manifesto', which signalled the end of foreign missions in China and articulated the link between foreign missions and imperialism.

The TSPM was (and is) not a church. It was placed under the direct supervision of the Religious Affairs Bureau (a state agency under the State Council), which in turn came under the authority of the United Front Work Department, which supervised and directed all relations with non-party groups. The RAB has been renamed the State Administration of Religious Affairs, SARA), but otherwise the structure has remained the same to this day. 
'Three Self' refers to 'self-governing, self-supporting and self-propagating', a concept first mooted in the nineteenth century and not a Communist invention; but from 1950 'Three Self' signalled a clear stand in relation to the 'foreign element' in the Chinese church and resulted in the expulsion of all foreign missionaries still in China.

No constructive thinking - and certainly no writing or publishing - went into what this Chinese church, free from 'foreign elements', should really constitute beyond a somewhat vague notion of an all encompassing, non-denominational structure. Many Chinese who had received theological training in the decades before 1949 and who could have contributed to the formation of a Chinese theology were lost, together with millions of other Chinese, in the political struggles during the years from 1958-1976 (Wielander 2013: 5-6). It was only in the 1980 s that a systematic effort went into the formulation of a Chinese theology.

\section{K.H. Ting's Theology - God is Love}

Love is a central aspect of all Christianity, but in contemporary Chinese Christianity it is of even greater importance. This particular emphasis on love in Chinese Christian theology is largely due to the efforts of one man. K.H. Ting, born to a Protestant mother in Shanghai in 1915, studied English and theology; he was trained and ordained in the Anglican Church. Like so many of his contemporaries, he wanted to use his belief to save Chinese society and the Chinese nation. His work for the YMCA, where he also met Wu Yaozong, the founder of the Three-Self Movement, had a huge influence on him; so did his work as pastor in the nondenominational, international church in Shanghai. He spent the years of 1946-1951 abroad to work and further advance his theological studies. But, like many Chinese intellectuals abroad at this time, he returned to Shanghai in 1951 to heed the call of the new communist government, which for many held great promise. In 1952 he became the Dean of the newly established Nanjing Jingling Theological Seminary and was ordained Bishop in 1955. Little 
tends to be mentioned about Ding's fate during The Great Leap Forward (1958) and the Cultural Revolution (1966-76). Like all intellectuals, he was subject to criticism and experienced hardship, but to his detractors, the fact that he did not suffer the same fate as other Christian leaders is reason enough to question his true piety and to wonder about the extent of his collaboration with the regime during this time. In keeping with the biographical pattern of all intellectuals who lived through twentieth-century China, Ting was reinstated to his previous position in 1980, four years after the end of the Cultural Revolution. In 1980 he was elected Chair of the Three-Self Patriotic Movement Committee, making him the most important Protestant leader in China, which remained the case until his death in 2012. (compare Tang 2015 and, in more detail, Wickeri 2007).

From 1980 the TSPM, under Ting's leadership, stepped up its work on the development of a Chinese Christian theology 'rooted in the Chinese soil'. Contrary to the general tenor of reports by Western media and Christian interest groups, the official Protestant church is very popular with believers. While many criticize the official Church for 'selling out', for being too secular and too accommodating of party policy, its success and appeal to all strata of society is undeniable, if not all-encompassing.

Love is the central tenet of the 'Reconstruction of Theological Thinking' in China and is built upon K.H. Ting's theology that stresses love as the supreme attribute of God. It is translated as the monosyllabic ai to set itself apart from bi-syllabic terms like aiqing (romantic love), but also traditional philosophical terms like jian'ai (a Mohist term) or the Confucian bo'ai, both usually translated as 'universal love' In Ting's (2004: 57) words: 'Only by acquiring a Chinese selfhood, a Chinese identity, can the Church of Jesus Christ in China live down its colonial past history and its image as something Western' (Ting 2004, 57). The central tenet of his theology was the move to a non-denominational Chinese church built on the core message that God is Love: 
'To know God as love is to say that the supreme attribute of God is not his power and might, nor his omniscience, nor his deity, nor his majesty and dominion and righteousness. Transcendence signifies the inexhaustibility of the cosmic love and immanence, the unfailing presence of that love in the whole creation.' (Ting 2004: 88)

Hand in hand with the importance of God's immanence in Ding's formulation goes his emphasis on the Christ-like God. The (official) Chinese Christian God is the God of the New Testament as embodied in Christ's attributes; it is the 'Cosmic Christ'. By emphasizing God's immanence in all creation and by focusing on his physical embodiment through Jesus Christ, Ting is emphasizing an immanence (over transcendence) that was also central to historical communism and which continues to be a central element of contemporary communist philosophy as articulated by Michael Hardt (2007) and Alain Badiou (2012), for example. It also builds on the significance of Jesus' historical life and 'good deeds' as evident in earlier theological debates on Christianity. Most importantly, it stands in contrast to the evangelical notion of God as transcendent source of all values, emphasized so strongly by Christian intellectuals and church leaders of a younger generation, like Yu Jie (1973-) or Wang Yi (1960s-) .

Ting's focus on the Christ-like nature of God and the universal extent of God's work, which is not limited to those who declare faith in God, allowed him to interpret socialist morality and ethics as a manifestation of Christ's nature. The cosmic Christ as drawn by Ting shows God as the cosmic lover, not as the cosmic tyrant or punisher. He works by education and persuasion rather than coercion and forced obedience, rejecting the standard metaphor of God as a father as unhelpful in the Chinese context. (The father figure in traditional Chinese culture is not associated with love and kindness.) His theology also puts less emphasis on the 
original sin than orthodox Christian theology does. This conception of God not only makes it possible to co-exist with or even embrace the ideals of communism, but is also sensitive to traditional Chinese culture, in particular Mencius, who posits that human nature is essentially good.

\section{A Chinese Language Theology - Hanyu Shenxue}

Supporters of Ting's theology claim that the exponential growth of Protestantism from the 1980s onwards is proof of its success and popularity with Chinese Christians. However, one could also argue that Ting's efforts at 'theological reconstruction', which really took off in the mid 1990s, were in fact a reaction to the growth of Protestant Christianity and the proliferation of different denominations and widely differing religious practices in China of the reform era. What aided the growth of Protestant churches in the 1980s was not so much the return to formal institutionalised religion through the reaffirmation of the Three-Self Patriotic Movement, but a combination of the following: the popularity of indigenous Christian groups founded by local Christian leaders; the re-appearance of the foreign missionary (usually in the form of the English teacher on campus); and the emergence, in the 1980s, of 'Cultural Christians', who studied the Bible as a the cultural foundation of the West rather than as a religious text. These studies laid an important foundation for the acceptance of and respect for Christian thought and values among non-believers, notably intellectuals and university students, in contemporary China. Their rational, humanistic studies of the Bible were a gateway into the Christian faith for many, including, in subsequent years, often the authors of these studies themselves (see for example Fallman 2004).

Out of these studies also emerged the call for a Sino-Christian theology, or a theology of the Chinese language, hanyu shenxue. At its heart lies the rejection of the very concept of 'indigenization' and the need for a 'translation' of Christian thinking. 
As one of its main proponents, Liu Xiaofeng, argues, Christian theology is a confessional and rational reflection and discourse on the Christ-event that presents itself as the Word of God. It is closely linked to the geographical, historical and linguistic context within which it is articulated. As such, Sino-Christian theology is juxtaposed with other historical forms of theology. Therefore, in the construction of Sino-Christian theology, the so-called issue of 'Sinification' does not exist, as it is grounded in the thesis that Christian theology is Western theology. As for the development of Sino-Christian theology, the foremost question to be considered is how the linguistic experiences of Chinese thinking receive, and discourse upon, the Christ-event and reflect on Christian confession. Therefore, Sino-Christian theology has to break away from the mind-set of indigenization or sinicization and face the Christ-event directly (Liu 2006: 74-5).

Liu argues further that Sino-Christian theology will develop from within its existing systems of thought and concepts of discourse and from within existing life experiences and linguistic expression. He refers to the type of Sino-Christian theology which expressed its Christian confession through a syncretism of Confucian, Taoist and Buddhist systems of thought. But he argues that it can also be expressed through the extraction of intellectual resources from Chinese classical poems and prose. In any case the understanding of the Christ-event should be rooted in the immediate and original life experiences of individuals rather than ethnic world-views. The basic direction of the construction of a Sino-Christian theology should therefore not be built on syncretism on the basis of existing ontological theories, be they Jewish, ancient Greek, Confucian, or Buddhist, but on the encounter with the original individual life experiences in the ethno-geographical linguistic fabric (Liu 2006: $77-8)$.

He Guanghu (2006: 108) echoes this when he says that one of the gravest mistakes in Chinese theology has been its over-dependence on ancient Confucian, Buddhist and Taoist 
scriptures at the expense of the resources of modern cultures since the twentieth century. He Guanghu also rejects the idea of an indigenized theology, preferring contextualized theology instead, as it does not lose the universality and generality of the faith. Furthermore, it sets out from the actual life experiences of human beings and seeks to provide answers to real-life questions (He 2006: 110). Here He makes the important point that the life experiences of Chinese speakers far exceed the 'indigenous context'. Sino-Christian theology therefore also must exceed the indigenous context of China and must include Chinese theologies outside the People's Republic. They should, however, all reach a consensus in their embrace of historical Chinese theology of the periods from the Nestorians to the religion of Erkeun (during the Yuan dynasty), the periods between Matteo Ricci and T.C. Chao, and the theological works written by Chinese in subsequent periods (He 2006: 110-11). In short, while He recognises the diversity of the Chinese experience across the globe, he also proposes a shared historical theological foundation for all of it.

In concrete terms, He Guanghu proposes three specific approaches to a Sino-Christian theology. First, it needs to be an 'inside out' approach, which sets out from the life experiences and cultural resources of Chinese speakers, focusing on the issues and struggles of their lives instead of providing ready-made dogmatic answers. In his view, this approach can only be adopted by Chinese theologians who have been brought up in their mother tongue and share the life experiences of Chinese people. However, the 'inside out' approach refers primarily to a certain mentality and hence does not rule out 'outside in' translation, that is, the translation of Western theological works into Chinese (He 2006: 113-4).

Another important point in He's Sino-Christian theological approach is the order of argumentation. In He's view, the doctrine of God must come before Christology. Seeing how important the figure of Christ, and in particular the historical Jesus was in the 'translation' of Christianity into the Chinese context of the early twentieth century, and how important Christ 
is in K.H. Ting's theology, this is a significant point of difference. He Guanghu argues that 'the Christology of Sino-Christian theology can only acquire its presupposition after SinoChristian theology's doctrine of God has been established on the grounds of Chinese speakers' belief in God (the terms used include 'God', 'Heaven', etc.)' (He 2006: 115).

Here we may encounter what Marian Galik has described as a 'cosmological gap between the Chinese and to a great extent, the Far Eastern world and the Western world [...] so wide that to bridge it seems almost impossible where religious belief is concerned' (2004: 1). Zha Changping - a classical scholar and house church leader-also cautions that comparisons between Chinese and Western culture, primarily Confucianism and the Bible, tend to overemphasize correlations and ignore essential differences. For example, the Chinese term for heaven (one of the terms on which to build a Sino-Christian theology according to $\mathrm{He}$ ), tian, can refer to four different things: material tian as opposed to earth; ethical tian as the highest truth in the cosmos; personal tian, which rules the cosmos, and the tian which controls man's faith (Zha 2008: 86). Zha also cautions that Logos is not the same as dao, the Chinese term chosen in the Chinese Bible to translate the former. While Logos is God becoming flesh and thus linking creation and salvation, dao in Chinese is an impersonal principle and law of the cosmos, a Confucian product of human moral thinking, which creates, but does not save (Zha 2008: 87).

\section{Chinese Christianity in an Inter-Connected World}

Zha Changping, born in the 1960s, belongs to the younger generation of theologians and church leaders, who found Christianity as a body of thinking through the works of 'cultural Christians', but who have themselves converted to Christianity, often following ideological disillusionment after 1989. For this generation, who grew up in a very different sociohistorical context to K.H. Ting and 'cultural Christians' like He Guanghu, the previous 
generations' emphasis on Christ's immanence and the ethical aspect of Christianity are far less important than God's transcendent nature. In a society characterised by scandal and corruption, where social trust and general levels of happiness have fallen, but where a sizable part of the population can now be described as middle-class, Christianity has become a very popular faith. Its main attraction lies in the provision of an all-encompassing belief system and in the powerful figure of a loving, transcendent God as a source of values, including, for some, political values (compare Wielander 2013: 130-50). K.H. Ting's immanent 'Cosmic Christ' has lost currency in this context. Even official church congregations have a strong evangelical character and appeals for Christian ethics to contribute to the state project by engaging in social work and charities tend to be dismissed as attempts to bring the Christian religion more firmly under government control.

This is partly the result of the increasing importance of global networks of ethnically Chinese missionaries, who play a key role in church planting and in theological training. This new 'Sino-Foreign elite' is the product of a global, interconnected world, in which the migrant plays an increasingly important role in translation. These (mostly) men, are not the type of 'cultural translators' Trivedi (2005) critiques as essentially disconnected from the cultures - and languages - they choose or are asked to 'translate' for the Western mind. They are also not Homi Bhaba's post-colonial 'translational transnationals' adding to the West's multiculturalism through Third World migration (Bhabha 1994: 173 in Trivedi 2005). They are mostly post-1989, white-collar intellectual migrants, who frequently move between China and their adopted new homes in the West (mostly the US) and are equally assimilated in both linguistic and cultural environments. They are joined by Chinese students and businessmen abroad, who bring their own understanding of Christianity into the world, lending a very different meaning to He Guanghu's 'inside out' approach. He Guanghu acknowledges their existence when he concedes that the life experiences of the Chinese far exceed the context of 
Mainland China, resulting in different Chinese theologies. What his approach does not provide is an answer to how these different Chinese theologies are meant to relate to one another beyond the recognition of their shared historical roots.

The official viewpoint in the face of this increasing diversity of Chinese theologies is unequivocal. Three years after K.H. Ting's death and two years into a new Chinese leadership under Xi Jinping (and nearly a hundred years after the publication of the Union Version), the new key term in Chinese official discourse on religion is zhongguohua, or 'China-fication'. The Chinese term zhongguohua implies an irrevocable change into something of China. Zhongguo indicates China as a country (although it is not the official name of the PRC); for people outside China it is now often synonymous with the PRC (and hence excludes Taiwan, Hong Kong and diasporic China). But the term also has a cultural and historical dimension, which is not confined to the boundaries or historical period of the PRC. The syllable hua, used as a suffix, implies irreversible change; huaxue is the Chinese term for chemistry. The term carries strong nationalist elements, which the English translation 'to sinify' does not convey. It was first mooted in 2012 by a Confucian scholar and has since been used in a programmatic sense in official discourse on Protestant Christianity in particular (Fiedler 2015).

In the foreword to the volume Christianity and the Construction of a Harmonious Society (Zhuo and Cai 2015), the vice-chair of China's Religious Affairs Bureau Jiang Jianyong lists all the requirements of the Protestant Christian faith when serving the Chinese dream, which include submitting oneself to the nation's benefit, safeguarding social stability, strengthening ethnic unity, and promoting the unity of the motherland. Jiang also insists on improving and strengthening unity within the faith. This is a clear theological directive, reaffirming the non-denominational and united character of the Protestant faith in China, which has always been an aspiration rather than a reality. Jiang's list of exhortations are 
followed by a stern reminder of the excellent tradition of social service which Christians are called to carry out. Christians are also exhorted to deepen reform and to enthusiastically open up to international communication while at the same time 'resolutely resisting infiltration' (Zhuo and Cai 2015: 8-10).

\section{Conclusion}

The publication of the Chinese translation of the Protestant Bible in the form of the Union Version in 1919 occurred at a high point of translational activity in China. From a Chinese perspective it was but one of many key texts of Western culture, science and technology introduced to a Chinese audience at the time. Then and now it was received as much more than just a religious text; for many its true revelation lay in the (spiritual) secret of the West's success. Sceptical of many core tenets of the faith, reform-minded, left-leaning intellectuals and theologians saw hope for China's salvation in actualizing the spirit of Jesus, thus focusing on the more rational, this-worldly aspect of the Christian faith. But the Union Version not only introduced the Protestant faith to a wider Chinese audience than ever before, but, as one of the first texts written in the new vernacular Chinese, it also contributed to the creation of this new written language, thus extending its influence on Chinese language and culture far beyond the original intentions of the translators.

These translators and cultural mediators had broken new ground in the translation process, questioning established paradigms and setting aside denominational differences in order to reach their aim of one universally accepted Chinese Bible, possibly as a basis for a united, non-denominational Chinese Church. This vision was both a hopeful projection onto China of what the Protestant Church in the West never achieved and a somewhat Orientalist approach denying the 'other' the possibility of diversity and multiplicity. They did not perhaps, at the time, wonder how this hypothetically unified Chinese Christian Church would 
communicate with a Christian faith and its organisations that is so decidedly diverse and disunited in the rest of the world. Their vision was formulated at a time when the interconnectedness of today's world was not yet technologically anticipated, and, during later periods of the twentieth century, also politically inconceivable.

Today Chinese Christians aim for new linguistic expressions of their faith, which emanate directly from Chinese lived experience rather than 'outside-in' translations requiring cultural sensitivity and mediation. They deny the need for 'Sinification' and indigenization at the same moment as the official discourse in China insists on 'China-fication' based on a strong nationalist and protectionist agenda. The Chinese example confirms that in the crosscultural encounter, the intentions of the translators and those of the many individuals, organisations and interest groups who read, interpret and adapt the translated text, rarely coincide. And yet the significance of the translated work far surpasses the realm of the religious context from which it emanated.

\section{Bibliography}

Badiou, A. (2012) In Praise of Love, London: Serpent's Tail.

Bays, D. (2012) A New History of Christianity in China, The Global Christianity Series. Malden, MA: Wiley-Blackwell.

Bhabha, H. (1994) The Location of Culture, London: Routledge.

Bieler, S. and C. Hamrin (2009) Guang yu Yan. Tansu jindai zhongguo gaige de shiwei lishi mingren (Salt and Light. Lives of Faith that Shaped Modern China), Beijing: Zhongguo dang' an chubanshe.

Chen, J. (2008) 'Modern Chinese Attitudes Towards the Bible', in C. Starr (ed.) Reading Christian Scriptures in China, London: T+T Clark, 13-31. 
Eber, I., S. Wan and K. Walf. (eds) (1999) Bible in Modern China. the Literature and Intellectual Impact, Monumenta Serica Monograph Series, Sankt Augustin: Monumenta Serica Institute.

Fallman, F. (2004) Salvation and Modernity. Intellectuals and Faith in Contemporary China, Stockholm: Stockholm University Press.

Fiedler, K. (2015) ‘More Than Just Old Wine in New Bottles - The ‘Sinification’ of Protestant Christianity as a Reaction to Current Religious Policy Issues in China'. Unpublished Conference Paper, Conference on Religion and Politics in Contemporary China, Olomouc (Czech Republic), 2-4 April 2015.

Galik, M. (2004) Influence, Translation and Parallels. Selected Studies on the Bible in China, Sankt Augustin: Institut Monumenta Serica.

Hardt, M. (2007) About Love [a video lecture], available at http://www.youtube.com/watch?v=ioopkoppabI [accessed 31 July 2015].

He, G. (2006) ‘The Methodology and Approaches to Sino-Christian Theology', in: H. Yang and D.H.N. Yeung (eds) Sino-Christian Studies in China, Newcastle: Cambridge Scholars Press, 106-119.

Keller, C.A. (1996) Making Model Citizens: The Chinese YMCA, social activism, and internationalism in Republican China, 1919-1937. Unpublished PhD Dissertation, University of Kansas.

Lin, M.M. (2010) Ethical Reorientation for Christianity in China. The Individual, Community, and Society, Ching Feng Series, Hong Kong: Christian Study Centre on Chinese Religion and Culture.

Liu, X. (2006) 'Sino-Christian Theology in the Modern Context', in H. Yang and D.H.N. Yeung (eds) Sino-Christian Studies in China, Newcastle: Cambridge Scholars Press, 52-89. 
Starr, C. (2008) 'Reading Christian Scriptures: The Nineteenth Century Context', in C. Starr (ed.) Reading Christian Scriptures in China, London: T+T Clark, 32-48. (ed.) (2008) Reading Christian Scriptures in China, London: T+T Clark.

Strandenaes, T. (2008) 'The Bible in the Twentieth-Century Chinese Christian Church', in C. Starr (ed.) Reading Christian Scriptures in China, London: T+T Clark, 68-80. Tang, X. (2015) 'Ding Guangxun “Sanzilun” zaiquan (A further explanation of Ding Guangxun's “Three-self Theory”)', in Jidujiao Yu Hexie Shehui Jianshe. Zhuo Xinping and Cai Kui (eds.), Beijing: Zhongguo shehui kexue chubanshe, 246-259.

Ting, K.H. (2004) God is Love, Colorado Springs: Cook Communications Ministries International.

Trivedi, H. (2005) 'Translating Culture vs. Cultural Translation', in: 91st Meridian 4, http://iwp.uiowa.edu/91st/vol4-num1/translating-culture-vs-cultural-translation [accessed 26 May 2015].

Wan, S. (1999) 'The Emerging Hermeneutics of the Chinese Church: The Debate Between Wu Lei-Chuan and T.C. Chao and the Chinese Christian Problematik', in Bible in Modern China: The Literary and Intellectual Impact, Irene Eber et.al. (eds), Sankt Augustin: Monumenta Serica Institute, 351-381.

Wickeri, P.L. (2007) Reconstructing Christianity in China. K.H. Ting and the Chinese Church, New York: Maryknoll.

Wielander, G. (2013) Christian Values in Communist China, London: Routledge. (2016) 'Chinese Dreams of Socialism. Visions of a Better Future', in L. Koenig and B. Chaudhuri (eds) Politics of the 'Other' in India and China. Western Concepts in Non-Western Contexts, London: Routledge, 139-52.

Yang, H. and D.H.N. Yeung (eds) (2006) Sino-Christian Studies in China, Newcastle: Cambridge Scholars Press. 
Yuan, J. (2006) 'Jindai xifang chuanjiaoshi dui baihua yingxiang (Modern Western Missionaries' Influence on baihua)' in Ershiyi shiji 98 (Dec 2006): 77-86. Zetzsche, O. (1999) The Bible in China. The History of the Union Version or The Culmination of Protestat Missionary Bible Translation in China, Monumenta Serica Monograph Series, Sankt Augustin: Monumenta Serica Institute.

Zha, C. (2008) 'Studying the New Testament in the Chinese Academic World: A Survey, 1976-2006', in C. Starr (ed) Reading Christian Scriptures in China, London: T+T Clark, 81-96.

Zhuo, X.and K. Cai (eds) (2015) Jidujiao yu hexie shehui jianshe (Christianity and the Construction of a Harmonious Society), Beijing: Zhongguo shehui kexue chubanshe. 